\title{
$\mathbb{A}$ Economics Bulletin
}

\section{Volume 41, Issue 2}

\section{The Effect of Pandemics on Domestic Credit: A Cross-country Analysis}

\author{
Gamze Ozturk Danisman \\ Kadir Has University
}

\author{
Ender Demir \\ Istanbul Medeniyet University
}

\begin{abstract}
Using a panel of 140 countries covering the period 1996-2018, this paper examines how previous pandemics (such as SARS, MERS, Ebola, Swine flu, etc.) have influenced the lending behavior of banks. We take advantage of a new index developed by Ahir et al. (2020) which measures discussions about pandemics at the country level. Our findings reveal that uncertainty related to pandemics significantly hamper domestic credit available to the private sector. The negative effect of pandemics on credit levels is more prevalent for the low-income \& emerging economies and nonOECD countries.
\end{abstract}

Citation: Gamze Ozturk Danisman and Ender Demir, (2021) "The Effect of Pandemics on Domestic Credit: A Cross-country Analysis", Economics Bulletin, Vol. 41 No. 2 pp. 444-456.

Contact: Gamze Ozturk Danisman - gamze.danisman@khas.edu.tr, Ender Demir - ender.demir@medeniyet.edu.tr.

Submitted: July 26, 2020. Published: April 09, 2021. 


\section{Introduction}

The World Health Organization declared the coronavirus (COVID-19) outbreak a pandemic; and the rapid spread of the disease globally has created an extreme challenge to the governments, firms, and households. The governments impose several restrictions including travel bans, border closures, general or limited curfew to flatten the curve. Stock returns, commodity prices, economic growth forecasts, and production declined globally; and the pandemic generated fear on all actors of society, financial markets being one of the first responders (Baker et al., 2020; Al-Awadhi et al., 2020).

The previous pandemics (such as SARS, MERS, Ebola, Swine flu, etc.) have not attracted much attention from researchers in finance and economic fields because their influences were generally local or regional ${ }^{1}$. However, due to the enormous global consequences of COVID19, there is a rising interest regarding examining its impact on stock markets (Baker et al., 2020; Zaremba et al., 2020, 2021; Demir and Danisman, 2021), firms (Albuquerque et al., 2020; Ding et al. 2020; Kaczmarek et al., 2021), individuals (Andersen et al., 2020), gold (Gharib et al., 2021), and cryptocurrencies, especially Bitcoin (Conlon and McGee, 2020; Corbet et al., 2020; Demir et al., 2020). Goodell (2020) provides a research agenda for the consideration of the possible financial and economic impacts of COVID-19. In this regard, the conservative lending behavior of banks is suggested as a topic to be explored for future research. As there is yet limited bank-level financial data to use for examining the possible effects of COVID-19, in this paper, we examine the impact of previous pandemics on domestic credit by using a panel of 140 countries covering the period 1996-2018 which might provide some insights for the case of COVID-19.

Banks are vulnerable in times of economic uncertainty by nature because of the increasing likelihood of loan defaults and bank runs during uncertain times (Goodell, 2020). A growing body of literature reveals that economic policy uncertainties due to their unpredictable nature confuse the actors in the business and lead to a significant reduction in bank credit availability and credit growth (Bordo et al., 2016; Caglayan and Xu, 2019; Gozgor et al., 2019; Hu and Gong, 2019; Danisman et al., 2020; Bilgin et al., 2020). Pandemic events induce an extreme type of uncertainty regarding how deadly the disease is, the fear of contagion, whether the restrictions imposed by the governments will be effective, the possible negative impacts on financial and economic conditions of the countries, and such. The level of uncertainty generated by the pandemic events is not comparable to any other uncertainty (such as the ones generated by economic crisis periods, shocks or economic policy uncertainties.), which is expected to adjust bank lending decisions and consumer behavior. Although the central banks use tools to support the flow of credit and ensure sufficient liquidity (IMF, 2020a), banks become rather reluctant to provide credit to the private sector as consumers or firms may not be able to repay their loans on a timely basis which would, in turn, imply a higher risk for bank assets (Gopinath, 2020). As, in general, the stages of pandemics are hard to predict (especially for the case of COVID-19), this can generate further fear and lead firms to cancel or postpone their investment decisions. Under such heightened uncertainty, a wait and see approach will be followed. Banks will also need to build loan loss provisions as firms will have solvency problems and nonperforming loans and write-offs are likely to increase (Korzeb and Niedziółka, 2020; Bitar and

\footnotetext{
${ }^{1}$ As of July 2020, a search of "Severe Acute Respiratory Syndrome" and "Finance" (Economics) in Google Scholar brings 10,300 (14,000) results while 11,900 (18,700) "COVID-19" and "Finance" (Economics) results are available since the outbreak.
} 
Tarazi, 2020). This will thus suffer deterioration in their capital adequacy positions and force banks to behave more conservatively in credit evaluations. Households also postpone their consumption except for the basic needs as their future cash flows are less certain. The duration of the pandemics becomes hard to predict; and households behave with a precautionary motive. The decrease in demand lowers economic activity and the reduction in lending magnifies the negative economic consequences arising from demand and supply shocks (Gopinath, 2020).

Motivated by the above discussions, in this paper, we analyze how previous pandemics affect domestic credits by using a panel of 140 countries covering the period 1996-2018. By doing so, we aim to generate insights into the possible impact of the COVID-19 on domestic credit levels and contribute to the emerging literature that examines the economic and financial impacts of the COVID-19 crisis. To our knowledge, we are the first in terms of using the newly developed index namely "Pandemic Discussions Index (PANDEMIC)" by Ahir et al. (2020) as a proxy for the magnitude of the pandemics. While the previous studies use dummy variables and the number of infected/death, this index is more comprehensive, has a wider scope covering economic uncertainty related to pandemics and other disease outbreaks; it is continuous, comparable across countries, and available for a longer time period (since 1996). Our findings indicate that pandemics significantly hamper global domestic credit levels. Moreover, this negative effect of pandemics is more observed in low-income \& emerging economies and nonOECD countries.

The rest of the paper is organized as follows. Section 2 explains the data and methodology. Section 3 presents and discusses the findings. The last section concludes the paper.

\section{Methodology and Data}

To explore the impact of pandemic events on domestic credit, we incorporate the following empirical models in line with Caglayan and Xu (2019) and Gozgor et al. (2019) for a crosscountry panel of 140 countries covering the period 1996-2018:

$$
\begin{aligned}
& \operatorname{CREDIT}_{j t}=\beta_{0}+\beta_{1} \text { PANDEMIC }_{j t}+\beta_{2} X_{j t}+\vartheta_{j}+\delta_{t}+\varepsilon_{j t} \\
& \operatorname{CREDIT}_{j t}=\beta_{0}+\beta_{1} \text { CREDIT }_{j t-1}+\beta_{2} \text { CREDIT }_{j t-2}+\beta_{3} \text { PANDEMIC }_{j t}+\beta_{4} X_{j t}+\varepsilon_{j t}
\end{aligned}
$$

where $\mathrm{j}$ and $\mathrm{t}$ stand for countries and time, respectively. Equation 1 is the baseline model; and Equation 2 is used for robustness estimations. CREDIT $T_{j t}, C_{R E D I T} T_{j t-1}$ and $C_{R E D I T} T_{j t-2}$ represent the current value, and the first and second lags of the extent of financial resources available to the private sector, respectively. The second lag of the variable CREDIT is included in Equation 2 due to persistency in second-order autocorrelation in the residuals. $\vartheta_{j}$ stands for bank fixed effects and $\delta_{t}$ stands for time fixed effects, respectively. Table 1 displays the definitions of variables along with descriptive statistics. The ending year of the sample period is selected as 2018 due to data availability in World Bank - World Development Indicators (WDI). The main dependent variable in the baseline estimations is domestic credit to the private sector as a percentage of GDP (CREDIT TO PRIV). We use the following two alternative dependent variables for robustness checks: domestic credit to the private sector by banks as a share of GDP (CREDIT TO PRIV BANKS) and the annual growth of credits/ deposits ratio (CREDIT GROWTH). 
Ahir et al. (2020) modify the previously developed "World Uncertainty Index" (Ahir et al. 2018) to capture the uncertainty regarding pandemics and have released a sub-index called Pandemic Discussions Index (PANDEMIC) at the global and country-specific level on April 4, 2020. The index is constructed by counting the number of times when a word related to pandemics is mentioned in the EIU country reports. To make it comparable across countries, the index is generated as the percentage of the words related to pandemic episodes in EIU country reports multiplied by 1,000. A higher number means a higher discussion about pandemics and vice versa. Figure A1 in the Appendix points out that the Pandemic index values increase dramatically in 2020. 2020 Q1 can be compared to previous outbreaks such as SARS, MERS, Ebola, Swine flu, etc., showing that uncertainty around the COVID-19 is much higher. The previous studies use Economic Policy Uncertainty Index (Bordo et al., 2016; Nguyen et al., 2020), World Uncertainty Index (Gozgor et al., 2019), Geopolitical Risk Index (Zhou et al., 2020 ) as proxies of uncertainty and investigate their influences on bank lending. As Table A1 shows, the correlations between Pandemic Index (PANDEMIC) and these above-mentioned indices are very low, showing that Pandemics Index captures a unique dimension of uncertainty and does not overlap with previously used measures.

In our empirical model presented in Equation 1, we use PANDEMIC as our main independent variable of interest. The PANDEMIC index is available quarterly in the database; and we convert the index from quarterly to yearly by taking simple quarter averages. We utilize an additional calculation method for the pandemic index, namely PANDEMIC V2 for robustness, which is calculated yearly weighted average with weights $1,2,3$, and 4 for the quarters Q1, Q2, Q3, and Q4, respectively.

$\mathrm{X}$ stands for control variables that are selected in line with the previous literature (see, e.g., Caglayan and Xu, 2019; Gozgor et al., 2019). As a source of data for country-specific variables, we use World Bank World Development Indicators, World Bank Global Financial Development Database, and World Bank Worldwide Governance Indicators. Specifically, in our baseline estimations, we use the annual percentage change in consumer price index (INFLATION), the share of assets in the three largest banks (CONCENTRATION); the natural logarithm of GDP per capita ( $L N G D P P C)^{2}$, the share of exports and imports in GDP (TRADE OPENNESS), and unemployment rate (UNEMPLOYMENT). Correlation coefficients among independent variables in the baseline model are relatively low, indicating no multi-collinearity issues (see Table 2). We also use the following country-level governance indicators to control for differences in the institutional environments such as the extent of political stability (POLITICAL STABILITY), the level of control of corruption (CONTROL OF CORRUPTION), and voice and accountability (VOICE \&ACCOUNTABILITY). The definitions and data sources of the governance variables are provided in Table 1 . Since these governance variables are highly correlated with each other and GDP per capita (see Table 2), these variables are not included simultaneously in the models but included one at a time.

Equation 1 is estimated using fixed-effects panel data estimation and the two-step system generalized method of moments (GMM) techniques is used for robustness when estimating Equation 2 (Arellano and Bover, 1995; Blundell and Bond, 1998). Fixed effects estimation is the standard technique in the literature and we use country and time fixed effects with robust standard errors to control for heterogeneity between countries and through time. To decide whether fixed or random effects is appropriate for our model, we employ the Hausman test for

\footnotetext{
${ }^{2}$ As a robustness check and to decrease the impacts of potential reverse causality, we also include the first lag of $L N G D P P C$ in the model instead of the current year value, and our findings remain robust.
} 
Table 1: Variable descriptions and descriptive statistics

\begin{tabular}{|c|c|c|c|c|c|c|c|}
\hline Variable & Definition & Data Source & Obs. & Mean & SD & Min & Max \\
\hline CREDIT TO PRIV & Domestic Credit to Private Sector as a percentage of GDP & $\begin{array}{l}\text { World Development } \\
\text { Indicators }\end{array}$ & 2969 & $47.10 \%$ & $44.87 \%$ & $0.19 \%$ & $233.21 \%$ \\
\hline CREDIT TO PRIV BANKS & $\begin{array}{l}\text { Domestic Credit to Private Sector by banks as Percentage } \\
\text { of GDP }\end{array}$ & $\begin{array}{l}\text { World Development } \\
\text { Indicators }\end{array}$ & 2974 & $43.79 \%$ & $40.43 \%$ & $0.19 \%$ & $223.10 \%$ \\
\hline CREDIT GROWTH & The annual growth of bank credit to bank deposits & $\begin{array}{l}\text { World Bank Global } \\
\text { Financial Development } \\
\text { (GFD) }\end{array}$ & 2826 & $4.69 \%$ & $15.61 \%$ & $-37.96 \%$ & $67.12 \%$ \\
\hline PANDEMIC & $\begin{array}{l}\text { A simple average of four quarters for the country-specific } \\
\text { index of discussion about pandemics. }\end{array}$ & $\begin{array}{l}\text { Ahir, H, N Bloom, and D } \\
\text { Furceri (2018) }\end{array}$ & 3360 & 2.96 & 17.47 & 0.00 & 438.98 \\
\hline PANDEMIC V2 & $\begin{array}{l}\text { Weighted average value (with weights 1,2,3 and } 4 \text { for Q1, } \\
\text { Q2, Q3 and Q4) of the country-specific index of discussion } \\
\text { about pandemics }\end{array}$ & $\begin{array}{l}\text { Ahir, H, N Bloom, and D } \\
\text { Furceri (2018) }\end{array}$ & 3360 & 3.07 & 18.90 & 0.00 & 438.18 \\
\hline INFLATION & The annual percentage change in consumer price index & $\begin{array}{l}\text { World Development } \\
\text { Indicators }\end{array}$ & 3024 & $9.42 \%$ & $80.64 \%$ & $-16.12 \%$ & $4145.11 \%$ \\
\hline CONCENTRATION & The share of assets of a country's three largest banks & $\begin{array}{l}\text { World Bank Global } \\
\text { Financial Development } \\
\text { (GFD) }\end{array}$ & 2721 & $67.86 \%$ & $19.46 \%$ & $17.16 \%$ & $100.00 \%$ \\
\hline LN GDP PC & $\begin{array}{l}\text { The natural logarithm of gross domestic product divided } \\
\text { by midyear population. }\end{array}$ & $\begin{array}{l}\text { World Development } \\
\text { Indicators }\end{array}$ & 3186 & 8.09 & 1.65 & 4.63 & 11.54 \\
\hline TRADE OPENNESS & $\begin{array}{l}\text { The sum of exports and imports of goods and services } \\
\text { measured as a share of gross domestic product. }\end{array}$ & $\begin{array}{l}\text { World Development } \\
\text { Indicators }\end{array}$ & 3117 & $80.74 \%$ & $48.97 \%$ & $0.03 \%$ & $442.62 \%$ \\
\hline UNEMPLOYMENT & $\begin{array}{l}\text { The share of the unemployed labor force in total labor } \\
\text { force }\end{array}$ & $\begin{array}{l}\text { World Development } \\
\text { Indicators }\end{array}$ & 2095 & $7.98 \%$ & $5.35 \%$ & $0.11 \%$ & $37.94 \%$ \\
\hline POLITICAL STABILITY & $\begin{array}{l}\text { The index measures perceptions of the possibility of } \\
\text { political instability and politically-motivated violence, } \\
\text { including terrorism. The index has a maximum value of } 2.5 \\
\text { and a minimum of }-2.5 \text {. }\end{array}$ & $\begin{array}{l}\text { World Bank Worldwide } \\
\text { Governance Indicators }\end{array}$ & 2800 & -0.24 & 0.97 & -3.18 & 1.76 \\
\hline CONTROL OF CORRUPTION & $\begin{array}{l}\text { It captures perceptions of the extent to which public power } \\
\text { is used for private interests which includes all forms of } \\
\text { corruption. The index has a maximum value of } 2.5 \text { and a } \\
\text { minimum of }-2.5 \text {. }\end{array}$ & $\begin{array}{l}\text { World Bank Worldwide } \\
\text { Governance Indicators }\end{array}$ & 2800 & -0.13 & 1.03 & -1.72 & 2.47 \\
\hline VOICE \&ACCOUNTABILITY & $\begin{array}{l}\text { The index captures the extent to which the country has } \\
\text { freedom of expression, freedom of association, and free } \\
\text { media as well as their citizens are able to participate in } \\
\text { selecting their government. The index has a maximum } \\
\text { value of } 2.5 \text { and a minimum of }-2.5 \text {. }\end{array}$ & $\begin{array}{l}\text { World Bank Worldwide } \\
\text { Governance Indicators }\end{array}$ & 2800 & -0.15 & 0.97 & -2.26 & 1.80 \\
\hline
\end{tabular}

Note: This table presents the variables, their brief descriptions, data sources and the descriptive statistics on all the variables used in our analysis. 
Table 2: Correlations

\begin{tabular}{|c|c|c|c|c|c|c|c|c|c|c|}
\hline & (1) & $(2)$ & (3) & (4) & (5) & $(6)$ & $(7)$ & (8) & (9) & $(\mathbf{1 0})$ \\
\hline (1) PANDEMIC & 1 & & & & & & & & & \\
\hline (2) PANDEMIC V2 & $0.98 *$ & 1 & & & & & & & & \\
\hline (3) INFLATION & -0.01 & -0.01 & 1 & & & & & & & \\
\hline (4) CONCENTRATION & $0.05^{*}$ & $0.06^{*}$ & $0.07 *$ & 1 & & & & & & \\
\hline (5) LN GDP PC & $-0.08 *$ & $-0.07 *$ & $-0.08 *$ & $-0.16^{*}$ & 1 & & & & & \\
\hline (6) TRADE OPENNESS & $0.10 *$ & $0.09 *$ & -0.03 & $0.12 *$ & $0.26^{*}$ & 1 & & & & \\
\hline (7) UNEMPLOYMENT & $-0.09 *$ & $-0.08^{*}$ & 0.01 & 0.03 & $-0.05^{*}$ & $-0.12 *$ & 1 & & & \\
\hline (8) POLITICAL STABILITY & -0.02 & -0.01 & $-0.08 *$ & $0.10^{*}$ & $0.64 *$ & $0.32 *$ & $-0.05^{*}$ & 1 & & \\
\hline (9) CONTROL OF CORRUPTION & $-0.04 *$ & -0.04 & $-0.06 *$ & $0.06^{*}$ & $0.77 *$ & $0.27 *$ & -0.03 & $0.75 *$ & 1 & \\
\hline (10) VOICE \&ACCOUNTABILITY & $-0.05 *$ & $-0.05^{*}$ & $-0.07 *$ & $-0.07 *$ & $0.63 *$ & $0.10 *$ & $0.11 *$ & $0.66^{*}$ & $0.79 *$ & 1 \\
\hline
\end{tabular}

Note: * represents significance at $5 \%$.

all specifications and the fixed-effect is confirmed by the Hausman test ${ }^{3}$. On the other hand, system-GMM accounts for the dynamic property of the dependent variable as well as autocorrelation and endogeneity problems. As documented in the literature (Caglayan and $\mathrm{Xu}$, 2019; Gozgor et al., 2019), domestic credit is significantly affected by its previous values; and therefore, we include first and second lags of domestic credit in Equation 2. Baltagi (2005) documents that the two-step system GMM is more efficient as compared to the one-step GMM; and thus, we incorporate the two-step system GMM for estimating Equation 2 with robust standard errors. We use right-hand side variables lagged twice or more as instrumental variables while making sure that the number of instruments is less than the number of countries (Roodman, 2009). We use collapsed instruments and implement orthogonal deviation transformations as suggested by Roodman (2009). We conduct several diagnostic checks to verify the relevance and validity of the GMM model, which includes the Sargan test, Hansen test, and AR (1), AR (2) and AR (3) tests for autocorrelation.

\section{Results}

Table 3 presents the baseline regressions that use fixed effect panel data estimation techniques. All specifications use CREDIT TO PRIV as the dependent variable. While Column 1 includes only PANDEMIC as an independent variable, Column 2 incorporates all other control variables in the baseline model. Columns $1 \& 2$ show that the coefficient of PANDEMIC is negative and significant, revealing that pandemics lead to a significant decrease in global domestic credit to the private sector provided by the financial sector. The coefficients are not only statistically but also economically significant. Specifically, the coefficient of PANDEMIC in Column 2 reveals that on average a 1 unit increase in pandemic index demonstrates a $0.107 \%$ decrease in domestic credit. Alternatively, we could interpret it as a 100 unit increase in the pandemic index, which leads to a $10.7 \%$ global decrease in domestic credits. It should be noted that this estimate is an average estimate for the period covering years from 1996 to 2018. However, around the pandemic years,

\footnotetext{
${ }^{3}$ Hausman test results confirm that fixed effects are better with a significant test statistic of magnitude 190.02.
} 
the index experiences dramatic increases. For instance, while the pandemic index has an average value of 2.96 for our sample covering the years 1996-2018, it reaches a value of 25.07 in the fourth quarter of 2014, corresponding to the Ebola outbreak. Besides, the index value is available for $2020 \mathrm{Q} 1{ }^{4}$, which helps with a better understanding of the impact of COVID-19. It has an average of 146.8 in 2020 Q1, which is significantly higher compared to other pandemics or outbreaks. Using the 2020 Q1 average (146.8) and our sample period's average value (2.96) of the PANDEMIC index, and the coefficient estimate of the PANDEMIC variable from our regressions, it is expected that COVID-19 will hamper domestic credit by approximately $15 \%$. The estimated magnitude of impact on domestic credit is expected to be much higher when we narrow our focus on years around pandemic periods or the period covering the COVID-19 pandemic. Although evidence on previous pandemics might help us to better understand the potential effect of the COVID-19 pandemic on domestic credits, there is a major limitation related to the novel nature of the COVID-19. While the previous pandemics were relatively regional and didn't have a significant impact on the economies, COVID-19 is global, affecting all economies and humanity. The countries perform several strategies such as lockdowns, curfews, and border closures to flatten the curve, leading to a slow-down in the economy. Moreover, the policies adopted by Central Banks and governments to mitigate the economic impact of the COVID-19 pandemic are completely different from the ones adopted in previous pandemics. Therefore, our estimations for the impact of the current pandemic on credits need to be considered cautiously.

Column 3 takes away the variable $L N G D P P C$ from the estimation and our results continue to hold. In Columns 4, 5 and 6, we add the following country-level governance indicators one at a time to control for differences in the institutional environments: POLITICAL STABILITY, CONTROL OF CORRUPTION and VOICE \&ACCOUNTABILITY ${ }^{6}$. We do not add governance variables simultaneously due to their high correlation with each other and also with $L N G D P$ $P C$. Our results remain consistent under these specifications. Column 7 in Table 3 uses the first lag of PANDEMIC as the independent variable; and the results remain robust. This shows that the lagged value of the pandemic index also has a significant negative impact on domestic credit and the mid-term effect of the pandemics on credit growth is prevalent.

As regards the control variables, we observe that higher GDP per capita, trade openness and unemployment significantly increase domestic credit levels (Caglayan and $\mathrm{Xu}, 2019$; Gozgor et al., 2019). A rising GDP per capita implies a growing economy which, in turn, increases the demand for credits. Likewise, credit demand related to imports and exports of goods and services is likely to increase as a country gets more integrated with the global economy. We also find that more concentrated banking systems have a dampening effect on global domestic credit. This implies that as the market power of banks increase (or competition between banks decreases), a decrease in credit growth is observed globally (Ashraf, 2018). The increase in the control of corruption and voice and accountability are associated with increases in credit levels (La Porta et al., 1998).

\footnotetext{
${ }^{4}$ We cannot use the index value for 2020 Q1 or 2019 because the data availability of other variables at the World Bank WDI is until 2018.

${ }^{5}$ We have calculated approximately as $146.8-2.96=143.84$ unit increase in the PANDEMIC index corresponding to $143.84 * 0.107 \%=15.39 \%$ decrease in domestic credit.

${ }^{6}$ We have also considered the Investment Freedom Index of the Heritage Foundation as an additional control variable in order to control for the level of freedom to invest in financial markets. Our results remain robust and they are available upon request.
} 
Table 4 displays the findings for robustness estimations. Column 1 uses the alternative pandemic index, namely PANDEMIC V2. Column 2 and 3 use CREDIT TO PRIV BANKS and CREDIT GROWTH as alternative dependent variables and the findings remain robust under these specifications and in line with Table 3. Column 4 and 5 use the two-step system GMM regressions with dependent variables being CREDIT TO PRIV and CREDIT TO PRIV BANKS, respectively. The findings reveal that there is persistency in credit growth. However, this relation turns to negative in the second lag. The coefficient of PANDEMIC is significantly negative under all specifications, which confirms our previous findings. The diagnostic checks of autocorrelation (with AR1 and AR2 being significant and AR3 insignificant) confirm the first-order and the second-order autocorrelation in the residuals, but the third-order autocorrelation is rejected. The insignificant p-values of Hansen and Sargan tests confirm the validity and reliability of our GMM models.

We investigate deeper in Table 5, and explore whether there are differences in the findings for different groups of countries where we consider CREDIT TO PRIV as the dependent variable. Columns 1 and 2 split the sample and display the findings separately for OECD vs. non-OECD countries. Columns 3 and 4 do the same Advanced vs. Low income- Emerging countries. The coefficients of the PANDEMIC variable appear to be significant only for the non-OECD and low income \& emerging countries. Columns 5 and 6 use interaction terms instead of split samples. In Column 5, we include the interaction term PANDEMIC*Non-OECD and the dummy variable Non-OECD in the model. Non-OECD is a dummy variable that equals 1 for Non-OECD countries and 0 otherwise. Column 6 incorporates the interaction term PANDEMIC*Low-Emerging and the dummy variable Low-Emerging in the model. LowEmerging is a dummy variable that equals 1 for low income and emerging countries and 0 otherwise. Both interaction terms in Columns 5 and 6 appear negative and significant, confirming the findings from Columns 1-4. This shows that previous pandemics dampen the financial resources of non-OECD and low income \& emerging countries. This result can be explained by the fact that the previous pandemics were relatively local and/or regional, and they generated negative consequences especially in low-income and emerging countries (Karabulut et al., 2020) ${ }^{7}$. However, it should be also noted that the current pandemic, COVID-19 is global; and many countries are highly affected. Therefore, the negative effect of the COVID-19 pandemic on credit growth is likely to occur for all countries regardless of the income level.

\footnotetext{
${ }^{7}$ Another potential reason is that there is not enough variation in the pandemic index for OECD and high-income countries during the sample period. For instance, while the standard deviation of the PANDEMIC index for OECD countries is 4.85; the corresponding standard deviation for non-OECD countries is 19.75 , which is not necessarily the case during the COVID-19 pandemic. PANDEMIC index indeed incorporates the uncertainty regarding the previous pandemics. We would like to thank the anonymous reviewer for this feedback.
} 
Table 3: Baseline estimations

\begin{tabular}{|c|c|c|c|c|c|c|c|}
\hline Dependent variable: CREDIT TO PRIV & (1) & (2) & (3) & (4) & (5) & (6) & (7) \\
\hline PANDEMIC & $\begin{array}{c}-0.055 * * * \\
(0.02)\end{array}$ & $\begin{array}{c}-0.107 * * * \\
(0.04)\end{array}$ & $\begin{array}{c}-0.116 * * * \\
(0.04)\end{array}$ & $\begin{array}{c}-0.106 * * * \\
(0.04)\end{array}$ & $\begin{array}{c}-0.106 * * * \\
(0.04)\end{array}$ & $\begin{array}{c}-0.109 * * * \\
(0.04)\end{array}$ & \\
\hline L.PANDEMIC & & & & & & & $\begin{array}{c}-0.146^{* * *} \\
(0.04)\end{array}$ \\
\hline INFLATION & & $\begin{array}{l}0.002 \\
(0.01)\end{array}$ & $\begin{array}{l}-0.007 \\
(0.01)\end{array}$ & $\begin{array}{c}0.102 * * \\
(0.05)\end{array}$ & $\begin{array}{c}0.096 * \\
(0.05)\end{array}$ & $\begin{array}{c}0.099 * \\
(0.05)\end{array}$ & $\begin{array}{l}0.001 \\
(0.01)\end{array}$ \\
\hline TRADE OPENNESS & & $\begin{array}{c}0.123 * * * \\
(0.03)\end{array}$ & $\begin{array}{c}0.086 * * * \\
(0.03)\end{array}$ & $\begin{array}{c}0.068 * * * \\
(0.03)\end{array}$ & $\begin{array}{c}0.067 * * \\
(0.03)\end{array}$ & $\begin{array}{c}0.068 * * \\
(0.03)\end{array}$ & $\begin{array}{c}0.131 * * * \\
(0.03)\end{array}$ \\
\hline UNEMPLOYMENT & & $\begin{array}{c}0.610 * * * \\
(0.16)\end{array}$ & $\begin{array}{c}0.449 * * * \\
(0.15)\end{array}$ & $\begin{array}{c}0.496 * * * \\
(0.16)\end{array}$ & $\begin{array}{c}0.483 * * * \\
(0.16)\end{array}$ & $\begin{array}{c}0.493 * * * \\
(0.16)\end{array}$ & $\begin{array}{c}0.712 * * * \\
(0.16)\end{array}$ \\
\hline POLITICAL STABILITY & & & & $\begin{array}{c}0.99 \\
(1.29)\end{array}$ & & & \\
\hline CONTROL OF CORRUPTION & & & & & $\begin{array}{l}0.2 * * \\
(2.19)\end{array}$ & & \\
\hline VOICE \&ACCOUNTABILITY & & & & & & $\begin{array}{l}3.457 * \\
(2.23)\end{array}$ & \\
\hline Constant & $\begin{array}{c}34.395 * * * \\
(1.24) \\
\end{array}$ & $\begin{array}{c}-45.013 * * * \\
(16.85)\end{array}$ & $\begin{array}{c}44.121 * * * \\
(3.91)\end{array}$ & $\begin{array}{c}42.090 * * * \\
(3.99)\end{array}$ & $\begin{array}{c}42.538 * * * \\
(4.02)\end{array}$ & $\begin{array}{c}41.630 * * * \\
(3.99)\end{array}$ & $\begin{array}{c}-45.663 * * * \\
(16.96)\end{array}$ \\
\hline R2 (Within) & 0.2524 & 0.2973 & 0.2842 & 0.2901 & 0.2898 & 0.291 & 0.3006 \\
\hline Observations & 2969 & 1739 & 1739 & 1556 & 1556 & 1556 & 1685 \\
\hline Number of Countries & 138 & 126 & 126 & 126 & 126 & 126 & 126 \\
\hline Country FE & YES & YES & YES & YES & YES & YES & YES \\
\hline Time FE & YES & YES & YES & YES & YES & YES & YES \\
\hline
\end{tabular}

Note: $*, * *, * * *$ represent significance at $10 \%, 5 \%$, and $1 \%$, respectively. Standard errors are given in parenthesis. 
Table 4: Robustness Checks

\begin{tabular}{|c|c|c|c|c|c|}
\hline & $\begin{array}{c}\text { (1) FE } \\
\text { PANDEMIC } \\
\text { V2 }\end{array}$ & $\begin{array}{c}\text { (2) FE } \\
\text { CREDIT TO } \\
\text { PRIV BANKS }\end{array}$ & $\begin{array}{c}\text { (3) FE } \\
\text { CREDIT } \\
\text { GROWTH }\end{array}$ & $\begin{array}{c}\text { (4) GMM } \\
\text { CREDIT } \\
\text { TO } \\
\text { PRIV }\end{array}$ & $\begin{array}{c}\text { (5) GMM } \\
\text { CREDIT TO } \\
\text { PRIV } \\
\text { BANKS }\end{array}$ \\
\hline PANDEMIC & $\begin{array}{c}-0.084 * * \\
(0.04)\end{array}$ & $\begin{array}{c}-0.079 * * \\
(0.04)\end{array}$ & $\begin{array}{c}-0.026 * * * \\
(0.02)\end{array}$ & $\begin{array}{c}-0.061 * * \\
(0.03)\end{array}$ & $\begin{array}{c}-0.051 * * \\
(0.02)\end{array}$ \\
\hline INFLATION & $\begin{array}{l}0.002 \\
(0.01)\end{array}$ & $\begin{array}{l}-0.001 \\
(0.01)\end{array}$ & $\begin{array}{c}0.03 \\
-0.026\end{array}$ & $\begin{array}{c}-0.229 * * * \\
(0.06)\end{array}$ & $\begin{array}{c}-0.210^{* * * *} \\
(0.06)\end{array}$ \\
\hline CONCENTRATION & $\begin{array}{c}-0.093 * * \\
(0.04)\end{array}$ & $\begin{array}{c}-0.128 * * * \\
(0.04)\end{array}$ & $\begin{array}{c}-0.03 * * * \\
(0.06)\end{array}$ & $\begin{array}{l}0.072 \\
(0.05)\end{array}$ & $\begin{array}{l}0.053 \\
(0.04)\end{array}$ \\
\hline LN GDP PC & $\begin{array}{c}10.095 * * * \\
(1.85)\end{array}$ & $\begin{array}{c}11.221 * * * \\
(1.81)\end{array}$ & $\begin{array}{c}10.323^{* * * *} \\
(3.24)\end{array}$ & $\begin{array}{l}-0.028 \\
(0.38)\end{array}$ & $\begin{array}{l}-0.055 \\
(0.29)\end{array}$ \\
\hline UNEMPLOYMENT & $\begin{array}{c}0.607 * * * \\
(0.16)\end{array}$ & $\begin{array}{c}0.634 * * * \\
(0.15)\end{array}$ & $\begin{array}{c}0.07 * * * \\
(0.27)\end{array}$ & & \\
\hline TRADE OPENNESS & $\begin{array}{c}0.123 * * * \\
(0.03)\end{array}$ & $\begin{array}{c}0.118^{* * * *} \\
(0.03)\end{array}$ & $\begin{array}{c}0.165^{* * * *} \\
(0.05)\end{array}$ & $\begin{array}{l}0.002 \\
(0.02)\end{array}$ & $\begin{array}{l}0.015 \\
(0.02)\end{array}$ \\
\hline L.CREDIT TO PRIV. & & & & $\begin{array}{c}1.234 * * * \\
-0.127\end{array}$ & $\begin{array}{c}1.400 * * * \\
-0.087\end{array}$ \\
\hline L2.CREDIT TO PRIV. & & & & $\begin{array}{c}-0.264 * * \\
-0.125\end{array}$ & $\begin{array}{c}-0.436 * * * \\
-0.083\end{array}$ \\
\hline CONSTANT & $\begin{array}{c}-45.522 * * * \\
(16.86)\end{array}$ & $\begin{array}{c}-53.322 * * * \\
(16.57) \\
\end{array}$ & $\begin{array}{c}4.312 * * * \\
(29.56) \\
\end{array}$ & & \\
\hline R2 (Within) & 0.2962 & 0.2556 & 0.157 & & \\
\hline Observations & 1739 & 1740 & 1736 & 2192 & 2194 \\
\hline Number of Countries & 126 & 126 & 125 & 128 & 128 \\
\hline Number of instruments & & & & 102 & 102 \\
\hline AR1 p-value & & & & 0.000 & 0.000 \\
\hline AR2 p-value & & & & 0.008 & 0.001 \\
\hline AR3 p-value & & & & 0.68 & 0.199 \\
\hline Hansen $p$-value & & & & 0.71 & 0.759 \\
\hline Sargan p-value & & & & 0.464 & 0.684 \\
\hline
\end{tabular}

Note: $*, * *, * *$ represent significance at $10 \%, 5 \%$, and $1 \%$, respectively. Standard errors are given in parenthesis.

\section{Conclusion}

This paper explores how previous pandemics influenced the lending behavior of banks by using a sample of 140 countries for the period 1996-2018. We use a novel index developed by Ahir et al. (2020), which measures discussions about pandemics at the country-level. Our findings indicate that the pandemics hamper domestic credit; and financial resources available to the private sector significantly deteriorate. The negative impacts are mainly prevalent for nonOECD, low income and emerging countries as compared to the OECD and advanced countries. We were not able to use 2020Q1 data in our analysis or include the impact of COVID-19 because the data for other macro variables in World Bank World Development Indicators were only available until 2018. However, using the 2020 Q1 average and our sample period's average value of the PANDEMIC index and the coefficient estimate of the PANDEMIC variable from our regressions, we predict that COVID-19 will lead to an average $15 \%$ yearly decrease in global credit. Of course, this negative effect might normalize or increase throughout the year, depending on the development of vaccines and containment success of countries. 
Table 5: OECD vs. Non-OECD Countries \& Advanced vs. Low Income-Emerging Countries

\begin{tabular}{|c|c|c|c|c|c|c|}
\hline $\begin{array}{l}\text { Dependent variable: } \\
\text { CREDIT TO PRIV }\end{array}$ & (1) OECD & $\begin{array}{l}\text { (2) Non- } \\
\text { OECD }\end{array}$ & $\begin{array}{c}\text { (3) } \\
\text { Advanced }\end{array}$ & $\begin{array}{l}\text { (4) Low- } \\
\text { Emerging }\end{array}$ & $\begin{array}{l}\text { (5) Non- } \\
\text { OECD }\end{array}$ & $\begin{array}{l}\text { (6) Low- } \\
\text { Emerging }\end{array}$ \\
\hline \multirow[t]{2}{*}{ PANDEMIC } & 0.086 & $-0.110 * * *$ & -0.071 & $-0.097 * * *$ & $0.222 *$ & -0.072 \\
\hline & $(0.16)$ & $(0.03)$ & $(0.08)$ & $(0.03)$ & $(0.13)$ & $(0.06)$ \\
\hline \multirow[t]{2}{*}{ PANDEMIC*Non-OECD } & & & & & $-0.330 * * *$ & \\
\hline & & & & & -0.132 & \\
\hline \multirow[t]{2}{*}{ Non-OECD } & & & & & $-28.863 * * *$ & \\
\hline & & & & & -6.789 & \\
\hline \multirow[t]{2}{*}{ PANDEMIC*Low-Emerging } & & & & & & $-0.025 * *$ \\
\hline & & & & & & -0.07 \\
\hline \multirow[t]{2}{*}{ Low-Emerging } & & & & & & $-45.086^{* * *}$ \\
\hline & & & & & & -6.871 \\
\hline \multirow[t]{2}{*}{ INFLATION } & $0.690 * * *$ & -0.007 & $4.089 * * *$ & -0.007 & 0.002 & 0.001 \\
\hline & $(0.15)$ & $(0.01)$ & $(0.74)$ & $(0.01)$ & $(0.01)$ & $(0.01)$ \\
\hline \multirow[t]{2}{*}{ CONCENTRATION } & -0.117 & $-0.154 * * *$ & -0.076 & $-0.178 * * *$ & $-0.105 * * *$ & $-0.118 * * *$ \\
\hline & $(0.09)$ & $(0.03)$ & $(0.10)$ & $(0.03)$ & $(0.04)$ & $(0.04)$ \\
\hline \multirow[t]{2}{*}{ LN GDP PC } & $28.282 * * *$ & $14.555 * * *$ & $37.439 * * *$ & $13.487 * * *$ & $11.434 * * *$ & $9.684 * * *$ \\
\hline & $(6.61)$ & $(1.58)$ & $(8.39)$ & $(1.47)$ & $(1.43)$ & $(1.43)$ \\
\hline \multirow[t]{2}{*}{ TRADE OPENNESS } & $-0.488 * * *$ & $0.248 * * *$ & $-0.133 * *$ & $0.282 * * *$ & $0.130 * * *$ & $0.109 * * *$ \\
\hline & $(0.08)$ & $(0.02)$ & $(0.05)$ & $(0.03)$ & $(0.02)$ & $(0.02)$ \\
\hline \multirow[t]{2}{*}{ UNEMPLOYMENT } & $1.627 * * *$ & 0.206 & $2.434 * * *$ & $0.326 * *$ & $0.504 * * *$ & $0.486 * * *$ \\
\hline & -0.361 & -0.142 & -0.47 & -0.128 & -0.148 & -0.147 \\
\hline \multirow[t]{2}{*}{ Constant } & $-191.346^{* * *}$ & $-82.303 * * *$ & $-315.555^{* * *}$ & $-78.415^{* * *}$ & $-39.862 * *$ & -10.483 \\
\hline & $(67.41)$ & (13.08) & -89.298 & -12.057 & $(15.71)$ & $(16.17)$ \\
\hline R2 (Within) & 0.424 & 0.450 & 0.387 & 0.468 & 0.480 & 0.537 \\
\hline Observations & 601 & 1138 & 527 & 1212 & 1739 & 1739 \\
\hline Number of Countries & 33 & 93 & 29 & 97 & 126 & 126 \\
\hline Country FE & YES & YES & YES & YES & NO & NO \\
\hline Time FE & YES & YES & YES & YES & YES & YES \\
\hline
\end{tabular}

Note: $*, * *, * * *$ represent significance at $10 \%, 5 \%$, and $1 \%$, respectively. Standard errors are given in parenthesis.

It is worth mentioning that banks are in a safer position as compared to the global financial crisis of 2008-2009 due to the capital and liquidity buffers that were brought thereafter. Some Central banks responded quickly and took actions to cope with the negative effects of COVID19 such as encouraging financial institutions to extend credit, securities purchases, decreasing funds rate, etc ${ }^{8}$. Those policies might help mitigate the impacts. However, it should be noted that COVID-19 is not like any other disaster. The previous pandemics were mostly regional; and limited restrictions were imposed. Therefore, the global consequences were relatively weaker; so national bank regulators need to implement broad coordinations at the international level and take necessary actions to maintain the availability of credit. Future research could focus on the comparison of the influence of pandemics on the flow of domestic credit in different sectors and investigate possible channels and outcomes.

\footnotetext{
${ }^{8}$ Please see IMF (2020b) for a detailed list of policy responses by country.
} 


\section{References}

Ahir, H., Bloom, N., and Furceri, D. (2018). "The world uncertainty index". Available at: https://papers.ssrn.com/sol3/papers.cfm?abstract_id=3275033

Ahir, H., Bloom N., and Furceri D. (2020). "World Pandemic Uncertainty Index". Available at: https://worlduncertaintyindex.com/data/

Albuquerque, R.A., Y. Koskinen, S. Yang, and C. Zhang. 2020. "Resiliency of Environmental and Social Stocks: An Analysis of the Exogenous COVID-19 Market Crash". The Review of Corporate Finance Studies, 9(3), 593-621

Al-Awadhi, A. M., Al-Saifi, K., Al-Awadhi, A., \& Alhamadi, S. (2020). "Death and contagious infectious diseases: Impact of the COVID-19 virus on stock market returns". Journal of Behavioral and Experimental Finance, 27, 100326.

Arellano, M., \& Bover, O. (1995). "Another look at the instrumental variable estimation of error-components models". Journal of econometrics, 68(1), 29-51.

Andersen, A.L., Hansen, E.T., Johannesen, N. and Sheridan, A., 2020. "Consumer responses to the COVID-19 crisis: Evidence from bank account transaction data". CEPR Discussion Papers $14809 . \quad$ Available at: https://cepr.org/active/publications/discussion_papers/dp.php?dpno=14809

Ashraf, B.N., (2018). "Do trade and financial openness matter for financial development? Bank-level evidence from emerging market economies". Research in International Business and Finance, 44, pp.434-458.

Baker, S., Bloom, N., Davis, S. J., Kost, K., Sammon, M., \& Viratyosin, T. (2020). “The unprecedented stock market reaction to COVID-19". Covid Economics: Vetted and Real-Time Papers, 1(3).

Bilgin, M. H., Danisman, G. O., Demir, E., \& Tarazi, A. (2020). Bank credit in uncertain times: Islamic vs. conventional banks. Finance Research Letters, 101563.

Bitar, M., \& Tarazi, A. (2020). A note on regulatory responses to COVID-19 pandemic: Balancing banks' solvency and contribution to recovery. Available at SSRN 3631131.

Blundell, R., \& Bond, S. (1998). "Initial conditions and moment restrictions in dynamic panel data models". Journal of econometrics, 87(1), 115-143.

Bordo, M. D., Duca, J. V., \& Koch, C. (2016). "Economic policy uncertainty and the credit channel: Aggregate and bank level US evidence over several decades". Journal of Financial Stability, 26, 90-106.

Caglayan, M., \& Xu, B. (2019). "Economic policy uncertainty effects on credit and stability of financial institutions". Bulletin of Economic Research, 71(3), 342-347.

Caldara, D. and Iacoviello, M., 2018. "Measuring geopolitical risk". FRB International

Finance Discussion Paper, (1222). Available at: https://www.federalreserve.gov/econres/ifdp/files/ifdp1222.pdf

Conlon, T. and McGee, R., 2020. Safe haven or risky hazard? Bitcoin during the COVID-19 bear market. Finance Research Letters, 35, 101607.

Corbet, S., Larkin, C. and Lucey, B., 2020. The contagion effects of the COVID-19 pandemic: Evidence from Gold and Cryptocurrencies. Finance Research Letters, 35, 101554.

Danisman, G. O., Ersan, O., \& Demir, E. (2020). Economic policy uncertainty and bank credit growth: Evidence from European banks. Journal of Multinational Financial Management, 57,100653

Davis, S.J., (2016). “An index of global economic policy uncertainty”. NBER Working Paper, w22740. Available at: https://www.nber.org/papers/w22740 
Demir, E., Bilgin, M.H., Karabulut, G. and Doker, A.C., (2020). "The Relationship between Cryptocurrencies and COVID-19 Pandemic". Eurasian Economic Review, 10(3), 349360.

Demir, E., \& Danisman, G. O. (2021). Banking Sector Reactions to the COVID-19: The Role of Bank-Specific Factors and Government Policy Responses (SSRN Scholarly Paper ID 3628261). Social Science Research Network. https://doi.org/10.2139/ssrn.3628261

Ding, W., Levine, R., Lin, C., and Xie, W. (2020). "Corporate immunity to the covid19 pandemic". Journal of Financial Economics, forthcoming.

Gharib, C., Mefteh-Wali, S. and Jabeur, S.B., (2021). "The bubble contagion effect of COVID-19 outbreak: Evidence from crude oil and gold markets". Finance research letters, 38, 101703.

Goodell, J.W., (2020). “COVID-19 and finance: Agendas for future research". Finance Research Letters, 35, 101512.

Gopinath, G., (2020). "Limiting the economic fallout of the coronavirus with large targeted policies", in R. Baldwin \& B. Weder di Mauro (eds), Mitigating the COVID Economic Crisis: Act Fast and Do Whatever It Takes. Centre for Economic Policy Research, London, pp. 41-48.

Gozgor, G., Demir, E., Belas, J., \& Yesilyurt, S. (2019). "Does economic uncertainty affect domestic credits? An empirical investigation". Journal of International Financial Markets, Institutions and Money, 63, 101147.

Hu, S., \& Gong, D. (2019). "Economic policy uncertainty, prudential regulation and bank lending". Finance Research Letters, 29, 373-378.

IMF, (2020a). "Federal Reserve Actions to Support the Flow of Credit to Households and Businesses." Available at: https://www.federalreserve.gov/newsevents/pressreleases/monetary20200315 b.htm

IMF, (2020b). "Policy Responses to COVID-19". Available at: https://www.imf.org/en/Topics/imf-and-covid19/Policy-Responses-to-COVID-19

Kaczmarek, T., Perez, K., Demir, E. and Zaremba, A., (2021). "How to survive a pandemic: The corporate resiliency of travel and leisure companies to the COVID-19 outbreak". Tourism Management, 84, 104281.

Karabulut, G., Bilgin, M.H., Demir, E. and Doker, A.C., (2020). "How Pandemics Affect Tourism: International Evidence". Annals of Tourism Research, 84, 102991.

Korzeb, Z. and Niedziółka, P., (2020). "Resistance of commercial banks to the crisis caused by the COVID-19 pandemic: the case of Poland". Equilibrium. Quarterly Journal of Economics and Economic Policy, 15(2), pp.205-234.

La Porta, R., Lopez-de-Silanes, F., Shleifer, A., \& Vishny, R. W. (1998). "Law and Finance". Journal of Political Economy, 106(6), 1113-1155.

Nguyen, C.P., Le, T.H. and Su, T.D., (2020). "Economic policy uncertainty and credit growth: Evidence from a global sample". Research in International Business and Finance, 51, 101118.

Roodman, D., (2009). "A note on the theme of too many instruments". Oxford Bulletin of Economics and statistics, 71(1), 135-158.

Zaremba, A., Kizys, R., Aharon, D.Y. and Demir, E., (2020). "Infected Markets: Novel Coronavirus, Government Interventions, and Stock Return Volatility around the Globe". Finance Research Letters, 35, 101597.

Zaremba, A., Kizys, R., Tzouvanas, P., Aharon, D.Y. and Demir, E., (2021). "The quest for multidimensional financial immunity to the COVID-19 pandemic: Evidence from international stock markets". Journal of International Financial Markets, Institutions and Money, forthcoming. 
Zhou, L., Gozgor, G., Huang, M. and Lau, M.C.K., (2020). “The Impact of Geopolitical Risks on Financial Development: Evidence from Emerging Markets" Journal of Competitiveness, 12(1), 93-107.

\section{Appendix}

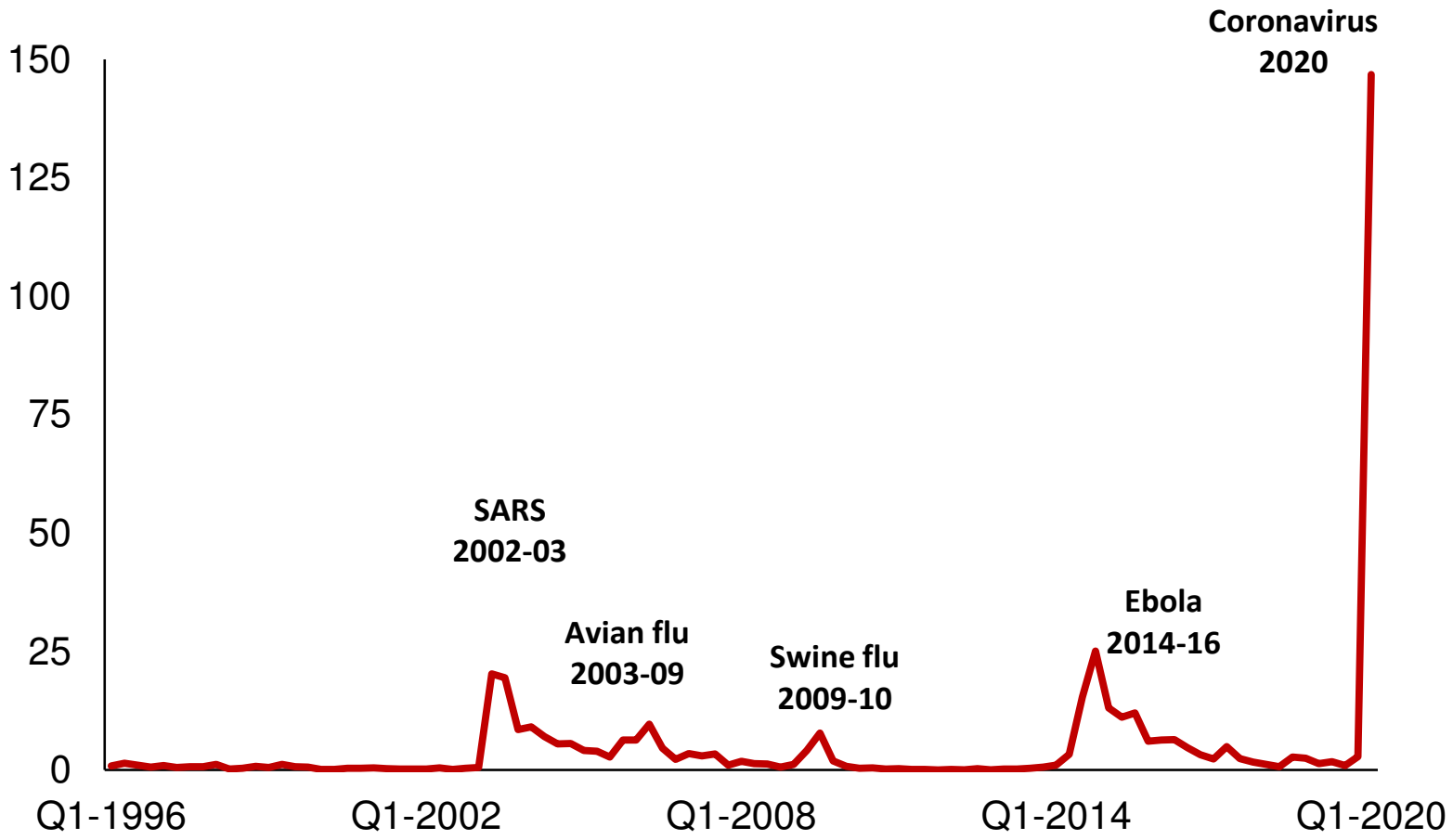

Figure A1. Pandemics Index 1996Q1 to 2020Q1

Source: Ahir et al. (2020)

Table A1. Correlation matrix between indexes

\begin{tabular}{|lrrrc|}
\hline & WUI & GPR & GEPU & $\begin{array}{c}\text { Pandemic } \\
\text { Index }\end{array}$ \\
\hline World Uncertainty Index (WUI) & 1.0000 & & & \\
Geopolitical Risks (GPR) & 0.3537 & 1.0000 & & \\
Global Economic Policy Uncertainty (GEPU) & 0.6471 & 0.3210 & 1.0000 & \\
Pandemic Index & 0.1285 & 0.1503 & -0.1111 & 1.0000 \\
\hline
\end{tabular}

Note: WUI (Ahir et al. 2018); GPR (Caldara and Iacoviello, 2018), GEPU (Davis 2016) 